\title{
FINANCIAL REPORTING IN \\ HYPERINFLATIONARY ECONOMIES
}

ISSN 1857-9973

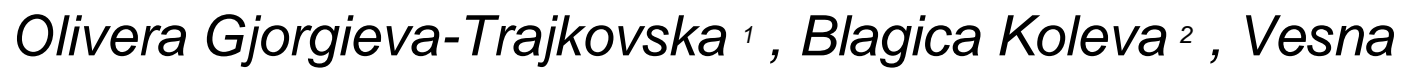
Georgieva Svrtinov ${ }^{3}$

${ }^{1}$ University Goce Delcev Stip, Faculty of Economics, olivera.trajkovska@ugd.edu.mk

2University Goce Delcev Stip, Faculty of Economics, blagica.koleva@ugd.edu.mk

${ }^{3}$ University Goce Delcev Stip, Faculty of Economics, vesna@ek-inst.ukim.edu.mk

\begin{abstract}
Hyperinflation is extremely fast or out of control inflation. Hyperinflation occurs when price increases are so wild that the concept of inflation is meaningless. When associated with depressions, hyperinflation often occurs while there is a significant increase in the money supply not supported by gross domestic product (GDP) growth, resulting in an imbalance in the supply and demand for the money. Left unchecked, this causes prices to increase, as the currency loses its value. The accounting, i.e. financial reporting applied to a foreign operation changes fundamentally when the economy in which it operates is determined to be hyperinflationary (highly inflationary). This, coupled with accounting differences between IFRS and US GAAP, means that identifying hyperinflationary economies is an essential step in the financial reporting process of a multinational dual reporter.
\end{abstract}

Key words: hyperinflation, financial, reporting, foreign, operations

\section{Introduction}

Accounting for foreign operations is often complex. It first requires companies to establish and maintain processes and controls to ensure the consistent application of accounting policies and the correct treatment of intercompany transactions on consolidation.

International groups then have the additional task of translating the balances, results and cash flows of foreign operations into the presentation currency. This is particularly challenging when the foreign operation is in a (potentially) hyperinflationary economy, for two main reasons.

- The assessment of whether or not the economy is hyperinflationary requires significant judgment, and it is often difficult to obtain stable and reliable inflation data from stressed economies to perform the analysis.

- The accounting for operations in hyperinflationary economies is inherently complicated. 
Dual reporters with foreign operations in a hyperinflationary economy face further complexity. IFRS and US GAAP have different accounting models for hyperinflationary economies that create GAAP differences in the numbers reported.

Both IFRS and US GAAP explicitly recognize that identifying hyperinflation requires judgment. But while the assessment methodologies are not aligned, conclusions about the hyperinflationary status generally do not diverge. [1]

IAS 29 lists five indicators of hyperinflation to be considered, along with any other relevant factors, when analyzing the economic environment of a country. One of these indicators is a cumulative inflation rate over three years approaching or exceeding 100 percent. However, this is not determinative and should not be considered in isolation.

These five indicators of hyperinflation, under IAS 29 are:

1. The general population prefers to keep its wealth in nonmonetary assets or in a relatively stable foreign currency. Amounts of local currency held are invested immediately to maintain purchasing power.

2. The general population regards monetary amounts not in terms of the local currency but in terms of a relatively stable foreign currency. Prices may be quoted in that currency.

3. Sales and purchases on credit take place at prices that compensate for the expected loss of purchasing power during the credit period, even if the period is short.

4. Interest rates, wages and prices are linked to a price index.

5. The cumulative inflation rate over three years is approaching or exceeds 100 percent.

In a hyperinflationary economy, reporting of operating results and financial position in the local currency without restatement is not relevant, as money loses its purchasing power at such a rate that comparison of amounts of events and transactions which have taken place at different times is misleading.

This standard prescribes the guidelines which are used by the entity whose currency is the currency of the hyperinflationary economy, to restate its financial statements in the measuring unit current at the end of accounting period.

International Accounting Standard 29 (IAS 29) Financial reporting in hyperinflationary economies, asserts that, in a hyperinflationary economy, financial statements "are useful only if they are expressed in terms of the measuring unit current at the balance sheet date". [2]

This standard is applicable to the financial statements of the entity from the start of the accounting period in which it identifies the existence of hyperinflation in the country in whose currency it reports.

\section{Restatement of financial statements}

According to IAS 29, the change in price levels over time can be the result of a variety of specific or general political, economic and social factors or forces. In specific factors can be classified changes in supply and demand and technological changes that can cause individual prices to grow or decline significantly, even independently of one another. General factors or forces can encourage changes in the general price level with the consequences of a general decrease in the purchasing power of money. In most countries, financial statements are prepared on a historical basis of the value (historical cost), which means at the purchase price for the acquired parts of the property, or at the cost price in respect of parts of the property realized in the production process, with the exception of assets (real estate, plants and equipment, investments) that can be revalued. However, there are economies in which legal entities present their financial statements on the basis of the current value, which implies that the effects of the change in prices are in the values of the property being held. In both cases price changes have direct or indirect impact on the financial statements, resulting from the above reasons. 
When a country's economy have the characteristics of a hyperinflationary economy, then financial reports of its entities, regardless of whether they are based on historical cost or current values, have use value only if they are expressed in terms of a measuring unit current at the balance sheet date.

The IAS 29 implies that the financial statements themselves contain the actual monetary terms, and not the effects of price changes reported through some balance item or in notes to the financial statements. So, there are no parallel presentation of financial statements with and without actual cash terms provided.

According the standard, financial statements reporting in the currency of a hyperinflationary economy, whether based on the historical or current value, should be expressed in current units of measurement on balance sheet date. With the presentation of the reporting accounting period in the measuring units current on the balance sheet date, it is necessary that the information relating to the comparative period is also disclosed in the same units of measurement as for the reporting position. Profit or loss on a net monetary position should be included in the net result and separately disclosed.

Preparation of financial statements in accordance with this standard is related to a particular procedures and assessments. IAS 29 emphasizes that consistent application of procedures and estimates from a period to a period is more significant than the exact determination of the deductible amounts included in the re-formulated financial statements. This provision can be interpreted so that the standard allows, for example, all income or expenses incurred in the same month (regardless of the dates of the creation) for practical reasons to be converted at the end of the year using the same coefficient for revaluation, although, as a rule, revaluation is made from the date of transaction, i.e. from date of origin of income and expenditure. [3]

\subsection{Restatement of financial statements when using historic cost}

The general requirement and substance of IAS 29 are all amounts from balance sheet and income statement which are not expressed in values current at the balance sheet date to be revaluated, using the general retail price index, from the date of acquisition, the occurrence of the transaction or the last revaluation until the balance sheet date.

All balance items are divided into monetary and non-monetary items and are translated to current vales, using rules established with this standard.

The entity will use general price index at reporting date, to restate the items in the statement of financial position to the currency units current at the end of reporting period as follows: [3]

- All the non-monetary assets and liabilities will be restated from the currency units at the date of purchase to the currency units current at the end of reporting period, using general price index such as plant and machinery, intangible assets and investment property.

- However, the non-monetary assets which are already stated at the amounts current at the end of reporting period, will not be restated, such as inventory at net realizable value and investments at fair value on reporting date.

- If some non-monetary assets are stated at the amounts other than the currency units current at the date of purchase (such as when a non-current asset has been revalued after the date of purchase), in this case such assets will be restated from the date of re-measurement to the to the currency units current at the end of reporting period..

- If the payment of a non-monetary asset is deferred in future without the interest charge, then such asset will be restated from the date of payment, rather than from the date of purchase to the currency units current at the end of reporting period.

- Monetary assets and liabilities such as receivables and payables are not restated as these are already stated at the currency units current at the end of reporting period. 
- The restated amount of the non-monetary assets should be not exceed its recoverable value, if this is the case then the asset will be written down to its recoverable value.

- The financial statements of the associate or joint venture which reports in a hyperinflationary economy will be first restated to the currency units current at the end of reporting period before the application of equity method.

- The components of equity are restated from the general price index at the start of the period or at the date when these components arose if it is later.

- If general price index is not available at the end of reporting then the entity will use the estimated movement in exchange rate between the functional currency and the relatively stable foreign currency.

- The general price index should reflect the change in general purchasing power.

- The retained earnings will be taken as a balancing figure.

- The restatement of assets and liabilities to the currency units at the end of reporting period may result it carrying values of such assets and liabilities being different from their respective tax bases, however such differences will be accounted for as per IAS 12.

In normal circumstances, income and expense are recorded at current values at the time of creation of income and expenses. This does not meet the requirements of this standard when it comes to hyperinflationary economies. Therefore, according to standard requirements, all items from the income statement incurred during the accounting period should be converted to the current unit of measurement on the balance sheet date, also by applying the general price index.

It is normal that any incurred income and expense will be revalued from the date of their creation until the last day of the accounting period, or until the balance sheet date, which certainly would not be a rational procedure, so the requirements of the standard can be satisfied by revaluation income and expenses incurred in the same month by the price index or the revaluation coefficient for that month compared to the end of the year.

IAS 29 requires that all items in the statement of cash flows be denominated in monetary units that are current at the balance sheet date. Since this report contains inflows and outflows of assets based on business activities, investment activities and funding activities that are realized during the period on a daily basis, here, as in the case of revenues and expenditures, it is proposed that monthly inflows and outflows are revalued. There should be used cash flow statement prepared using the direct method, i.e. using gross values of individual positions.

The entity should also restate the comparative amounts relating to the previous reporting period to the currency units at the end of reporting period using the general price index, irrespective of whether these are prepared on the basis of historical cost method or a current cost method. The entity should also restate the financial information disclosed in the previous periods.

A parent entity prepares consolidated financial statements for the group (parent company and dependent legal entities) after converting the separate financial statements to domestic currency from the end of the reporting period, using the general price index, in accordance with this standard. When dependent entity is operating abroad, its restated financial statements are transferred to consolidated financial reports at the final exchange rate. According to the standard, if a dependent entities abroad does not report in the currency of the inflationary economy, their financial statements are treated in accordance with IAS 21.

If financial statements of different reporting dates are consolidated, all items non-monetary or monetary should be converted to the current unit of measurement on the date of consolidated financial statements.

\section{Example:}

A company invested EUR 100 in June 2013 and $\$ 200$ in July 2016. The restated value of these investments for December 2017 is EUR 568: 
June 2013

130

$330 / 130=2.54$

Restatement

factor

Recorded cost

100

254

Restated cost
July 2016

210

$330 / 210=1.57$

200

314
Dec. 2017

Total

330

$330 / 330=1$

\subsection{Restatement of financial statements when using current cost}

The items in the statement of financial position stated at current cost at the end of reporting period need not to be restated as these are already stated at currency units current at the end of reporting period. All other items will be restated using general price index at the end of reporting period.

The incomes and expenses in the statement of profit or loss are stated at their current amounts at the date of transaction therefore, all the incomes and expenses should be restated from the amounts at the date of transaction to the currency units current at the end of reporting period.

\section{Economies ceasing to be hyperinflationary and required disclosures}

When an economy ceases to be hyperinflationary and an entity discontinues the preparation and presentation of financial statements prepared in accordance with this IAS 29, it shall treat the amounts expressed in the measuring unit current at the end of the previous reporting period as the basis for the carrying amounts in its subsequent financial statements.

An entity shall made the following disclosures:

(a) the fact that the financial statements and the corresponding figures for previous periods have been restated for the changes in the general purchasing power of the functional currency and, as a result, are stated in terms of the measuring unit current at the end of the reporting period; (b) whether the financial statements are based on a historical cost approach or a current cost approach; and

(c) the identity and level of the price index at the end of the reporting period and the movement in the index during the current and the previous reporting period.

The disclosures required by this standard are needed to make clear the basis of dealing with the effects of inflation in the financial statements. They are also intended to provide other information necessary to understand that basis and the resulting amounts.

\section{Comparative national regulation and practice}

Inflation accounting practices vary throughout the world and are usually functions of the rate and degree of impact of inflation. Countries that have high or hyperinflationary conditions tend to 
have more requirements for inflation accounting than countries with moderate or low inflation rates.

In the US and UK, inflation accounting such as GPP (General Purchasing Power designed to maintain the real purchasing power of capital and shareholder's equity by accounting for changes in the general level of prices) and current value (concerned with the rise or fall in the cost of specific assets, not with loss of general purchasing power of a currency) were required in the late seventies and early eighties when inflation was high. These were subsequently dropped after cost-benefit analyses proved them to be ineffective. Now GPP and other inflation adjustments are provided for on a volunteer basis. [4]

In continental Europe and other developed countries, inflation accounting is encouraged but not required. As inflation falls and compliance costs exceed benefits, corporations and analysts have little regard for the usefulness of such systems.

In South America, inflation is much more influential on accounting requirements. In countries such as Brazil, Argentina, and Mexico, high rates of inflation have resulted in more legal requirements for inflationary accounting systems.

Companies in the Netherlands are not required to use current cost accounting, but many provide information supplementary due to the philosophies and history of current value accounting in the Netherlands. Professor Theodore Limperg and the company Philips were both pioneers in the field of current cost accounting.

Limperg is considered the father of replacement theory accounting and believed income should not be earned without maintaining the source of income from a going-concern standpoint. Income is a function of revenues and replacement values, not historical costs.

Philips was one of the first to prepare current value financial statements, which it used first in 1936 for internal cost accounting and then in 1952 for external reporting purposes.

\section{Advantages of IAS 29}

IAS 29 provides relatively few requirements for adjusting financial statements of a company reporting in a hyperinflationary economy. The figures in the resulting adjusted financial statements should convey the same meaning as those derived from conventional financial statements when stable prices prevail.

IAS 29 has an important advantage over other standards dealing with inflation-adjustments of financial statements, because: It places high importance on arriving at usable information rather than stressing detailed recording and computational procedures, as can be seen from the following. "The restatement of financial statements in accordance with this standard requires the application of certain procedures as well as judgment. The consistent application of these procedures and judgments from period to period is more important than the precise accuracy of the resulting amounts included in the restated financial statements." (IAS 29, paragraph 8).

Furthermore, IAS 29 suggests use of an independent professional assessment in cases where detailed records of acquisition dates are not available.

As such, IAS 29 should be classified within Dewhirst's two higher level accounting theory models. These two higher level models are: [5]

1) The Substance Oriented Model, which "emphasizes both the balance sheet and income statement to represent the economic situation of the accounting entity", and

2) The Needs Oriented Model, which emphasizes "user decision making information satisfaction", rather than a Procedure Oriented Model, which accounts for processing transactions under generally accepted accounting principles.

\section{Illustration of adjustment of balances as a result of hyperinflation}


An entity in a hyperinflationary economy commenced business on 1 January 2016. It is required to restate its financial statements in accordance with IAS 29. All non-monetary assets were acquired on the first day of trading. There is no depreciation and inventories are purchased on a just-in-time basis. At 1 January 2016, net monetary assets were 2.000 EUR . [4]

Assume profits generate cash evenly over the year.

The relevant indices are:

$\begin{array}{lc}1 \text { January 2016 } & 100 \\ 30 \text { June 2016 } & 110 \\ 31 \text { December 2016 } & 120\end{array}$

The following table sets out the amounts recorded in the unadjusted statement of financial position and the adjustments required under IAS 29.

Table 1 Adjustment of statement of financial position

\begin{tabular}{llll}
\hline Balances at 31 December 2016 & $\begin{array}{l}\text { Unadjusted statement of } \\
\text { financial position } \\
\text { EUR }\end{array}$ & $\begin{array}{l}\text { Adjustment } \\
\text { Non-monetary assets }\end{array}$ & $\begin{array}{l}\text { Inflation adjusted } \\
\text { balances } \\
\text { EUR }\end{array}$ \\
\hline Net monetary assets & 10.000 & $120 / 100$ & 12.000 \\
\hline & 5.000 & 5.000 \\
\hline Opening equity & 15.000 & $120 / 100$ & 17.000 \\
\hline Profit for the year & 12.000 & $120 / 110$ & 3.273 \\
\hline & 3.000 & & \\
\hline Loss on monetary assets: & 15.000 & $(120-100) / 100$ & $(400)$ \\
\hline $\begin{array}{l}\text { EUR 2.000 held all year } \\
\text { EUR 3.000 generated during }\end{array}$ & & $(120-110) / 110$ & $(273)$ \\
\hline year & & & \\
\hline
\end{tabular}

17.000

\section{Conclusion}

Conventional financial statements of a company are based on the assumption that the monetary unit is stable. Under inflationary conditions, however, the purchasing power of the money declines, causing some crucial figures of the conventional financial statements, especially net income and nonmonetary assets value to be distorted. 
Financial statements without adequate adjustment to inflation do not reflect appropriately the financial position and performance of business entities. Furthermore, unadjusted financial statements can be meaningless or even misleading under inflationary conditions. Several countries have implemented different adjustment procedures resulting in lack of uniformity. A uniform solution to the problem of assessing financial performance of entities in an inflationary environment has been long overdue.

The accounting, i.e. financial reporting applied to a foreign operation changes fundamentally when the economy in which it operates is determined to be hyperinflationary (highly inflationary). Accounting for foreign operations is often complex. It first requires companies to establish and maintain processes and controls to ensure the consistent application of accounting policies and the correct treatment of intercompany transactions on consolidation.

Dual reporters with foreign operations in a hyperinflationary economy face further complexity. IFRS and US GAAP have different accounting models for hyperinflationary economies that create GAAP differences in the numbers reported.

International Accounting Standard 29 (IAS 29) Financial reporting in hyperinflationary economies, asserts that, in a hyperinflationary economy, financial statements "are useful only if they are expressed in terms of the measuring unit current at the balance sheet date".

This standard is applicable to the financial statements of the entity from the start of the accounting period in which it identifies the existence of hyperinflation in the country in whose currency it reports.

\section{References}

[1] "Hyperinflationary economies", IFRS Institute, 2017

[ 2 ] International Accounting Standards Board (IASB), 2005:1259.2

[ 3 ] Milojevic, I., Segrt, S., "Financial reporting in hyperinflationary economies according IAS", 2016

[ 4 ] www.iasplus.com/en/standards/ias/ias29

[ 5 ] Goldschmidt, Y., Yaron, J., "Application of International Accounting Standard 29", Working paper, World Bank, 2005

[ 6 ] A. Hosseini, "Accounting for price changes and inflation internationally", 2015

[ 7 ] The Institute of Chartered Accountants, "International Financial Reporting Standards", 2008 